\title{
Designing a quality management system at ebpc engineering and business process consultants, S.C.
}

\section{Diseño de un sistema de gestión de la calidad en ebpc consultores de ingeniería y procesos de negocio, S.C.}

RAMÍREZ-ROMÁN, Adolfợ, SUÁREZ-ÁLVAREZ, Ángel, CHABAT-URANGA, Jacqueline and RODRÍGUEZ-RODRÍGUEZ, Luis Alberto

Universidad Veracruzana, Facultad de Ingeniería Mecánica y Ciencias Navales. Calle Salvador Díaz Mirón 35, Zona Universitaria, 91090 Xalapa-Enríquez, Ver.

ID $1^{\text {st }}$ Author: Adolfo, Ranírez-Román / ORC ID: 0000-0002-3820-8582, Researcher ID Thomson: S-5868-2018, arXiv Author ID: adolramirez, PubMed ID: adolramirez, CVU CONACYT ID: 244749

ID $1^{\text {st }}$ Coauthor: Ángel, Suárez-Álvarez / ORC ID: 0000-0002-0726-9630, CVU CONACYT ID: 946964

ID $2^{\text {nd }}$ Coauthor: Jacqueline, Chabat-Uranga / ORC ID: 0000-0003-2202-1032, CVU CONACYT ID: 464993

ID $3^{\text {rd }}$ Coauthor: Luis Alberto, Rodríguez-Rodríguez / ORC ID: 0000-0002-6118-040X, Researcher ID Thomson: W-93162019, CVU CONACYT ID: 1011993

DOI: $10.35429 /$ EJRP.2019.9.5.12.23

Received July 25, 2019; Accepted December 18, 2019

\section{Abstract}

The following investigation focuses on the design of a Quality Management System, incorporating principles and key concepts in the design of a flexible and competitive system and the certification's normative. The success is complemented with the management direction with a focus in continuous upgrades with a basis on the efficiency and effectiveness of every established process in it's model. The purpose is to implement a system to the organization Engineering and Business Process Consultants (EBPC). analyzing the context of the organization, as well as the good practices that are carried out. The impact is consolidated in gaining experiences in the process of applying international standard criteria and the development of the "Operations Management and Innovation" knowledge generation line of the Academic Corps of the EP industrial engineering "Innovation in Management Systems" UV-CA-470 consisting of the Analysis and improvement of management models and systems.

\begin{abstract}
Resumen
La presente investigación se enfoca en el diseño de un Sistema de gestión de la Calidad (SGC), incorporando principios y conceptos claves de desarrollo un sistema flexible competitivo y su normativa para su certificación. El éxito se complementa con la dirección de su gestión con un enfoque de mejora continua, a través de su eficiencia y eficacia de cada proceso establecido en su modelo. El propósito es implementar un sistema en Engineering and Business Process Consultants (EBPC), analizando el contexto de la organización, involucrando las buenas prácticas. La principal aportación es realizar un diseño de sistema de gestión, que permita la estandarización de los procesos con un ambiente de mejora continua y expectativas de acreditación, dando pauta a que la organización sea competitiva en su entorno industrial, estableciéndose cinco procesos para su funcionamiento eficaz. El impacto se consolida en la obtención de experiencias y buenas prácticas durante la investigación con apoyo de la línea de generación del conocimiento "Gestión e Innovación de las Operaciones" del Cuerpo Académico del PE de Ingeniería Industrial "Innovación en Sistemas de Gestión" UVCA-470 que consiste en el Análisis y mejora de los modelos y sistemas de gestión.
\end{abstract}

Sistema, Modelo, Calidad

Citation: RAMÍREZ-ROMÁN, Adolfo, SUÁREZ-ÁLVAREZ, Ángel, CHABAT-URANGA, Jacqueline and RODRÍGUEZRODRÍGUEZ, Luis Alberto. Designing a quality management system at ebpc engineering and business process consultants, S.C. ECORFAN Journal-Republic of Peru. 2019. 5-9: 12-23.

\footnotetext{
$\dagger$ Researcher contributing first author.
} 


\section{Introduction}

The research was carried out through the diagnostic stage in the processes of the Management System of the Engineering and Business Process Consultants (EBPC) organization, analyzing the context of the organization, good administrative practices, the elaboration of a proposed Model of Management to standardize activities and generate an environment of continuous improvement with support from the advisory service. It focuses on the design of a Quality Management System (QMS) which is aimed at being proactive, incorporating key principles and concepts, which allows to face the competitiveness of the industrial sector of project design generating a structure that allows incorporating requirements of different ISO standards for certification, a flexible system with different disciplines. Therefore, controlling an organization requires systematic management improving its efficiency and effectiveness of quality management.

\section{Organization Context}

Engineering and Business Process Consultants (EBPC) is a proudly Mexican company, which was created in 2009 , formed with the mission of offering solutions implementation and integration services, focused mainly on the oil sector, EBPC offers engineering, automation, services optimization and control of industrial processes. The company has a project area made up of Technical Inspection and Verification (ITV) and Procurement and Construction Engineering (IPC), in ITV different tests of nondestructive tests are carried out which for its proper operation requires processes accredited by the Mexican Accreditation Entity (EMA). To be more competent in the preparation of nondestructive test tests and as a verifying unit EBPC has the vision of being accredited before EMA, under the standards NMX-EC-17025IMNC-2017 General requirements for the competence of test laboratories and calibration, and NMX-EC-17020-IMNC-2014 Conformity assessment - Requirements for the operation of different types of units (body) that performs the verification (inspection), respectively, for which it is desired to design a QMS, having as Model ISO 9001: 2015, to implement, with requirements that give the customer confidence, quality of services, taking into account the ISO 9001 family with the structural model of the Deming cycle.
The model will strengthen an efficient document control system for accreditation in NMX-EC-17025-IMNC-2017 and NMX-EC17020-IMNC-2014, being an innovative support in the ITV area, where tests are carried out Reliable and efficient non-destructive integrating the requirements with ISO 9001.

There is a quality policy in the company, which is appropriate for the organization's turn, works as a frame of reference to establish quality objectives, and contain a commitment to continuous improvement. All stakeholders in the company have knowledge of the organization, which includes employees, customers and even suppliers, it all depends on the context.

The competence, the awareness, and the communication that is had with the personnel, are part of the requirements that the company needs in the processes and its objectives considering the necessary resources to satisfy the needs of the client, with trained personnel, tools, equipment and material, suitable for service.

The Non-Conformities detected during the development of the service, its actions and impact are essential, verifying the effectiveness of the process interaction. Also, actions are evaluated through quality tools.

One of the most obvious reasons, for which the design of the management system is needed, is to apply clause 8 of the NMX-EC17025-IMNC-2017 standard and of the NMXEC-17020-IMNC-2014 standard, generating an integration platform with effective evidence and feedback from interested parties.

\section{Management Model Design}

The design of a QMS determines how the organization complies with the guidelines of ISO 9001: 2015, also, it considers a set of national and international standards and standards, contributing to a service executed with specifications. The design of the QMS considers the ISO 9001: 2015 principles, fostering improvement and confidence in the performance of operations. The principles of quality management are: customer focus, leadership, people commitment, process approach, improvement, evidence-based decision making and relationship management. 
The requirements and principles requested in the International Standard are applicable to all organizations, regardless of the type, size, or products and services provided.

A QMS ensures customer satisfaction and the business permanence of the organization. Therefore, the importance of its design is to guarantee quality services in accordance with its context, quality policy, internal and external resources of the company, interaction and process performance. And, when the principle of continuous improvement is met, the organization generates standards, which it reviews, evaluates and controls periodically through inspections, management review, quality circles, executive meetings and internal or external audits. The document control procedure is implemented by reducing the risks in the interaction of the processes. A reliable implementation, staff is notified through memorandum, notices or training sessions contribute to an effective service, including the design of formats or procedures consistent with the job description and daily activities.

Depending on the turn and type of company, it is how the QMS is diagnosed, designed and implemented to be used as an effective management tool, with faithful control of the processes; as well as customer feedback considerations with international recognition.

The design of the QMS is elaborated for a company that wishes as a base a management system, with the vision of incorporating the requirements of the NMX-EC-17025-IMNC2017 and NMX-EC-17020-IMNC-2014 standards synchronized in its Supply chain and effective, achieving accreditation considering the revision times of the regulations by its technical committee. A culture of continuous improvement is maintained, and a training structure with staff competencies; as well as documentary, preparing new documents or updating those that are already registered in the checklists.

\section{Management model}

Quality is an important tool for organizations today, good practices and areas of opportunity are generated, so organizations seek the accreditation of their Quality Management System (QMS).
The organization has a process map and the design of a QMS, proposed based on the analysis of the context of the organization. During the development of the process map, as well as the manual, a solid and effective structure was consolidated, useful for the management system according to the following graphic representation (see figure 1):

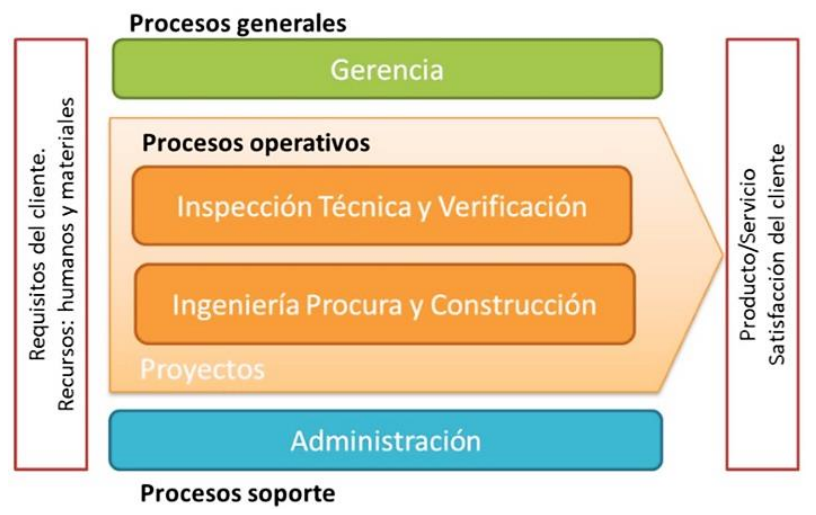

Figure 1 Process Map of the EBPC Organization

Where:

Technical Inspection and Verification (ITV)

Procurement and Construction
Engineering (IPC)

Operational processes:

The operative processes have contact with the external clients according to the requirements requested by the client and determine the necessary resources and materials. They generate the output related to the project and having the completion of the product / service, customer satisfaction, in the same way as the feedback of this, which increases the value that is had in the value chain of the organization. The operational processes are part of the project department, which is divided into IPC and ITV, where the security department is located.

\section{General processes:}

Its function is to support the key processes, providing outputs which supply the key processes. These processes consider the external and internal clients of the organization. The general process is part of the management of the organization where the marketing and contract departments are located, which has direct contact with the company's management. 
Support processes:

They generate exits which help the operational processes, but, in a more indirect way than the general processes, they are responsible for providing the operational processes with the support resources, whether material or human, that are required to carry out their functions. without setbacks the support processes are made up of the accounting, maintenance, systems, purchasing and human resources departments. In this way, the organization aspires to be a leader in the organization's turn, carrying out quality projects, where the process map is a key tool, to strengthen the internal communication of the QMS. The EBPC organization only has 4 processes that interact with each other for the proper functioning of this, the project department is divided into two ITV and IPC processes, these have the same inputs, however, according to the type of project requested where it is determined which of the processes is the one that will be carried out. In the regenérales processes only the management process is had, due to the structure that is counted in the company and the way in which the information is handled it is feasible to have only the general process in which two departments are found. There is a support process in which several departments are included, which are responsible for managing all the support resources that may be needed in the ITV and IPC processes.

In the Quality Manual of the organization, the design of the QMS is determined, which conforms to the requirements of ISO 9001: 2015, which mentions the interpretation of the requirements of the standard, however, the content is adjusted to the practices and culture of the organization. The management system is adequate and is only applicable in this, it facilitates the detection of an area of opportunity in the development of internal auditing and the effective decision making by those responsible for the process in conjunction with the management, in the same way allows to have information and feedback on customer satisfaction, quality objectives and policies are defined which allow the organization to take quality actions, and measure its performance. The system that was designed for the organization guarantees to the clients that the services or products are planned, reviewed, controlled and established in accordance with the standards that are had within the organization or which were requested by the same client.

ISSN-On line: 2414-4819

ECORFAN $^{\circledR}$ All rights reserved.
The management system guarantees customers and the organization that the services or products offered are planned, reviewed, controlled and executed according to standards established in the organization or based on standards applicable to these.

The QMS is supported by documented information which facilitates communication about the intentions of the organization and the objectives of the management system in a clear manner. This documentation is a tool used to generate value to the EBPC system processes, and the documented information is made up of: quality policy, quality manual, procedures, programs and key documents, work instructions and records, all this offers controlled information with its traceability, and to the activities that are carried out through its interaction and control and evaluation mechanisms.

The EBPC quality manual is a document that remains active and changing, which is developed in accordance with the management system. The quality objectives that are established are reached in the time that is determined in accordance with the format to achieve objectives that the organization has being monitored for its adjustments in the indicators or determine if it happens to be a standard or part of the organization's policies , with the purpose of being a guide of the management system. The principles established in the manual are communicated to the organization, so that they are understood by its members and in this way determine what their responsibility is within the management system. Within the manual the scope of the QMS that is being designed is defined, as well as the requirements that are needed. On the other hand, the quality manual includes what is necessary for the management of resources, the realization of products and the measurement, analysis and improvement of the organization. Also, the quality manual is fully integrated into the work (for example, See Figure 2 flow chart, and Figure 3 control sheet as part of the organization's manual. 
December 2019 Vol.5 No.9 12-23

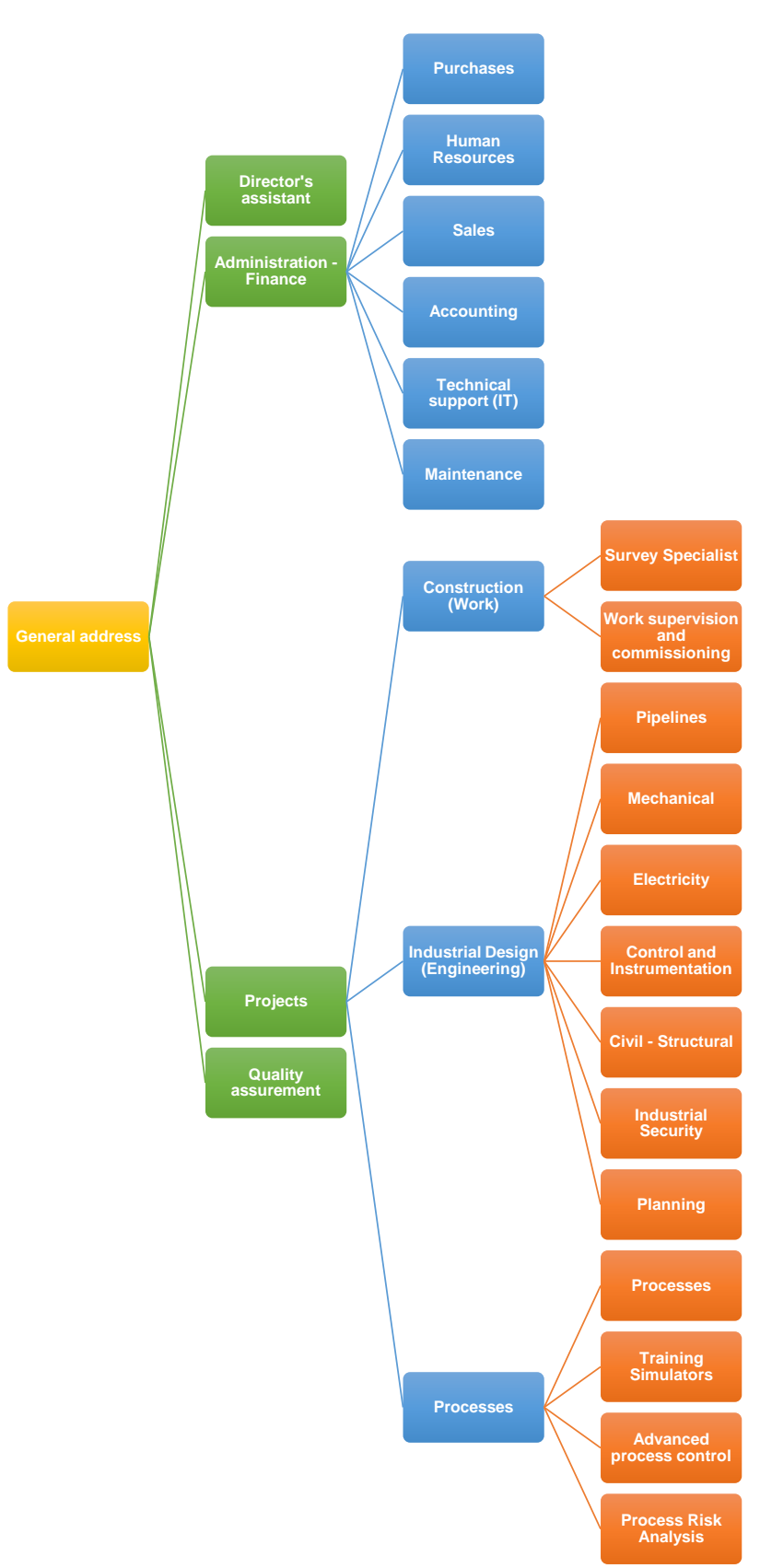

Figure 2 Organization chart of the organization

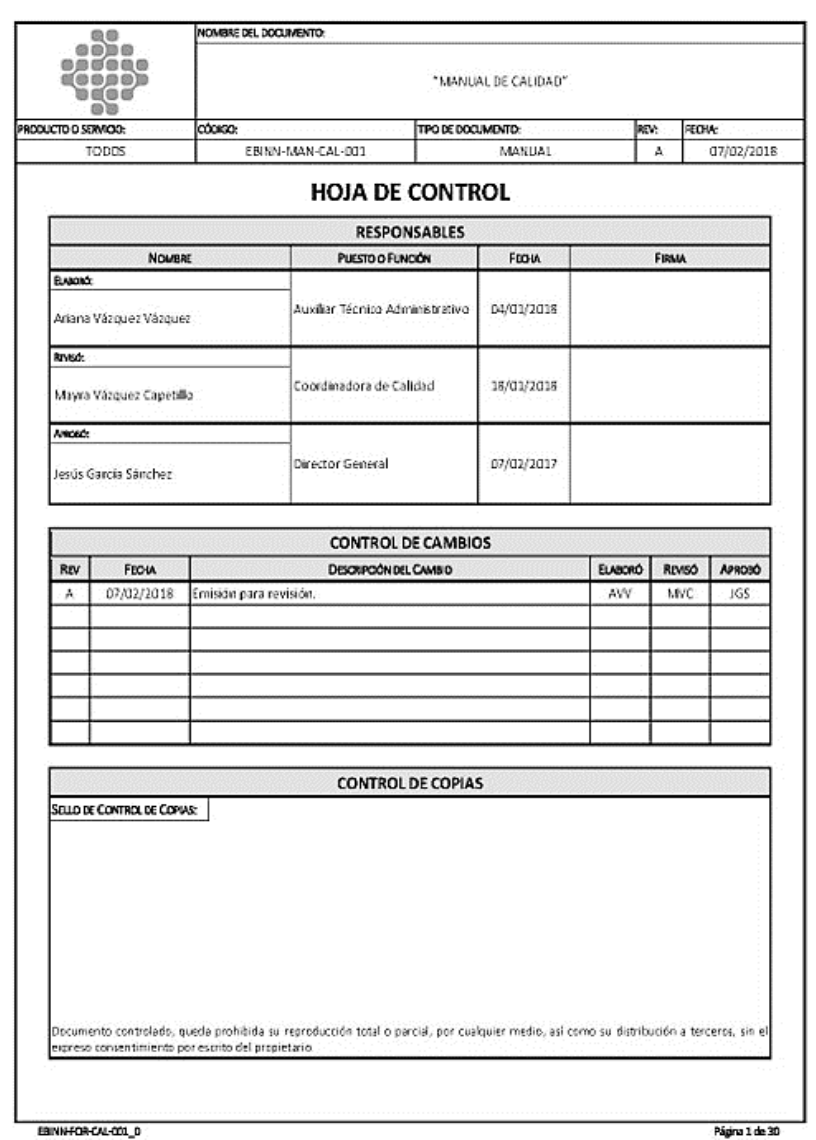

Figure 3 Quality Manual Control Sheet

\section{Technical information}

In the first stage a Gantt chart was developed, which is a tool that describes the activities and the time for its execution, so in this the activities that were carried out during the development of the QMS design are detailed. which was approved by the director of the company.

The purpose of the development of the work program is that it acts as a guide during the development of the project, which details the steps necessary to carry out the design of the QMS.

The review was carried out, the context of the organization through a SWOT analysis and the PESTEL methodology that consists in determining the Political, Economic, Social, Technological, Ecological, and Legal factors, which, strengths, opportunities, weaknesses were terminated. and threats that it may have in the organization and guide the analysis of the context of the company. 
Once the analysis of the context of the organization was carried out, it began with the review of the mission, vision and values, in order to verify whether the quality policy that is available in the organization is adequate and aligned with Strategic planning Subsequently the assessment of the documented information held in the organization was carried out in accordance with the requirements of ISO 9001: 2015, considering a detailed study of the standard (taking into account all the "must", "should" and "may "That are in this), the findings were reported to the general director of the organization.

In the second stage, a meeting was held with the Director General and the managers of the departments of administration, projects and quality assurance, in which the director gave the order for each manager of the different departments to be involved in the documentary development from the SGC. The administrative documentary part is in charge of the Administration Manager, the Project Manager is in charge of the technical part and the Quality Assurance Manager is in charge of the quality management part, the documented information is controlled by agreement with a series of lists which are: master list of documents, in which key is described, revision, date, name, person in charge, list for format control, where the key, name, person in charge, location and time are described of reception of each document, also, these two lists are separated according to the processes that are had in the organization, these lists allow a control of the own documents of the organization and avoid the duplication of some code or some document, and In this way there is a list of records, which are documents of the organization, as well as procedures and formats that are provided For another entity, these lists allow to speed up the search for documents.

A meeting was held with the staff, applying the brainstorming tool with the purpose of starting with the process map, understanding the operation of the organization and helping to improve it, establishing the scope of the process map. To start with the structure, a process diagram was made, describing the activities of the organization to execute a project, then the processes with which the organization has are defined, and the inputs and outputs are determined.
Once the process map was determined, it was given the task of generating each of the processes, of drafting the quality objectives of the organization according to its process, which serve as a guide to achieve goals established in the strategic planning, and during the meeting the elements to improve the organization were identified, once identified, the goal was continued to establish the objective, following the guidelines of the organization. During the meeting the quality indicators were established, such as control parameters in the processes, as well as the elaboration of a risk matrix in each of the active projects.

The documents are divided by department, where the key requirements were established to channel them to the Quality Assurance department where they are reviewed, and subsequently for approval with the Director General. The procedures developed for the QMS have a format, with their instructions and identified with an internal code.

With the information available from EBPC, the organization's quality manual was integrated, which allows us to understand the operation of the organization, either for staff or for external persons and new staff.

\section{Methodology}

For the development of the project, it required a methodology of observation and application of technical terms of the ISO 9000 family through the development of the Quality and Productivity Tools diploma of the Faculty Continuing Education program with authorization key DEC032 -17; where the research and development work of the proposal was carried out applying the four modules of the diploma that consisted of the tools of innovation, in the control evaluation, process control and continuous improvement. The research for the development of the proposal was carried out during a period of six months, period from January 2018 to June 2018 in the company Engineering and Business Process Consultants, S.C. also known as EBPC, located on Calle 20 de Abril number 317, in the Francisco Villa neighborhood in the city of Veracruz. This organization started activities in 2009, on the initiative of the current owner who serves as General Director. With nine years in the market, the organization has strengthened its structure. 
The company's business refers to scientific and technical consulting services, where the main services it offers are: basic engineering, extended basic engineering, cost estimation, specialized process simulation, specialized process equipment design, simulator development for operator training, implementation of real-time monitoring systems, implementation of operational reliability systems, among others. In the following two figures, some of the organization's projects are identified:

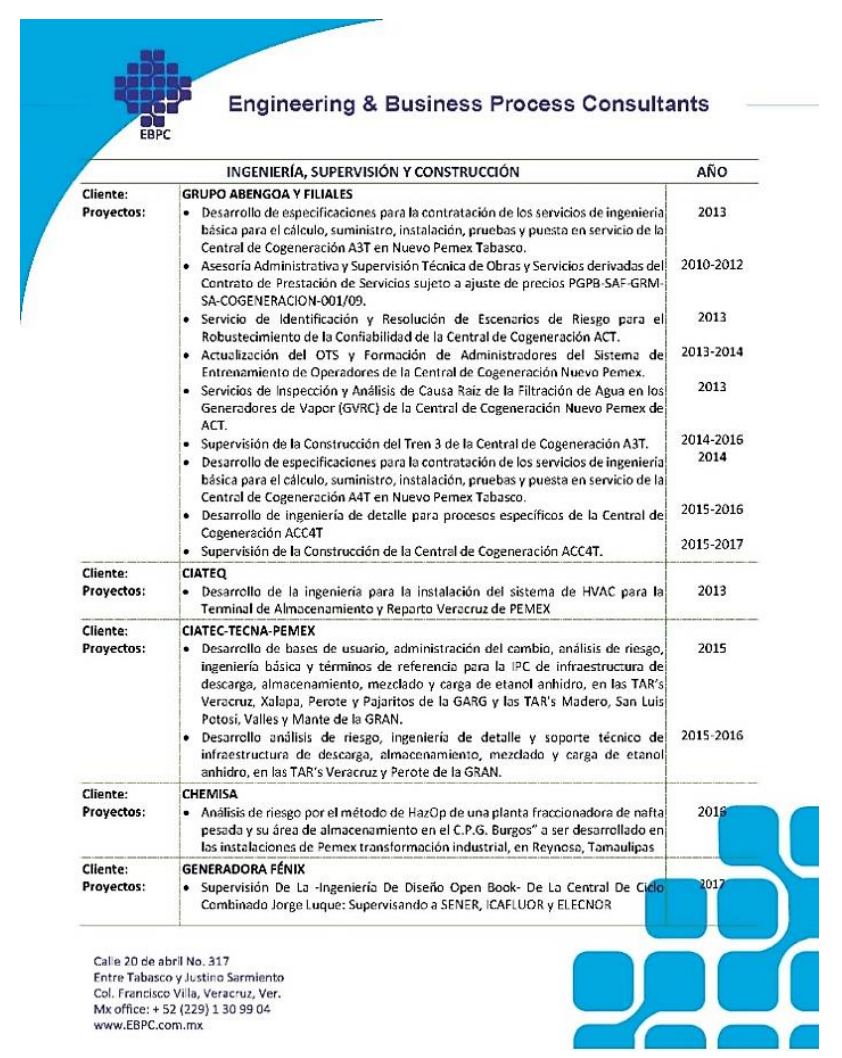

Figure 4 Example of organizational projects (Page 3 of the Organizational CV)
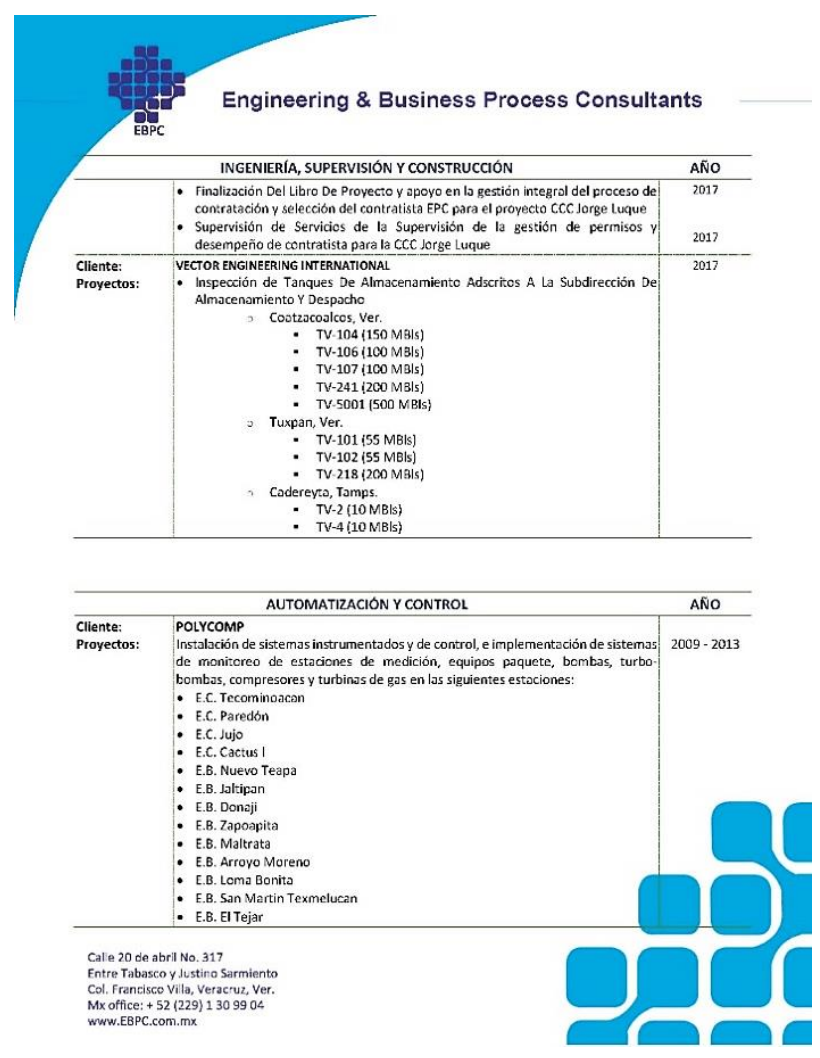

Figure 5 Example of organizational projects (Page 4 of the Organizational CV)

These projects have been part of the documentation and implementation of the Quality Management System. The functional areas of the organization are identified as administration - finance, projects and quality assurance. The research is consolidated based on the company's concern about the demands of the sector in which it is located, a competitive environment, the organization designs a QMS which, provides guidelines for the implementation and accreditation of other specific regulations in its sector, which are necessary for the organization. In order to achieve the objectives, set in the investigation, the requirements of ISO 9001: 2015 were implemented. Therefore, it was necessary to ask questions of the personnel in the different areas, in order to obtain reliable information for the design of the system structure and this is adequate for the company. Also, responding to a qualitative approach, allowed the collection of information from the organization and analyze the organizational structure. On the other hand, it is also a descriptive - explanatory study, according to the important properties of the factors. To design the QMS in any organization, a work plan must be generated, which allows the object to be reached. 
Each of the activities which make up the stages for the design of the QMS is described through an analysis of the organization, considering the cause-effect tool, identifying the current situation, in order to know its reality, the design of the system is indispensable the collection and classification of information, to provide an overview of their strengths and weaknesses.

The strategies that were created for the design of the SGC of the EBPC organization were the establishment of the contact and communication channel with the top management and the managers of the different departments, in the same way we established contact with Teachers of the Veracruzana University, with who had advice during the design of the QMS for the EBPC organization. It was also necessary to review the ISO 9001: 2015 standard to define the requirements to be met, and with the objective of acquiring knowledge about this standard, a workshop-workshop on "Interpretation of the ISO 9001: 2015 Standard" was attended in the facilities of the Faculty of Mechanical Engineering and Naval Sciences, of the Universidad Veracruzana.

And, the dissemination strategy is carried out through the following platforms of the Veracruzana University:

- Information System for university linkage (https://dsia.uv.mx/sivu/).

- Research registration and evaluation system https://dsia.uv.mx/sirei/).

- Thesis Repository in the Library System of the Veracruzana University.

To determine the current situation of the organization, and carry out the design of the QMS, full access to the existing documentation of the organization, which was related to the QMS, was obtained during the collection of information, meetings and small interviews that they had with the staff, especially those with more years of work, it was reported that previously the organization started the design of the QMS based on ISO 9001: 2008, however it was a project that required the transition period for its consolidation.
The design stage of the EBPC QMS, has ten activities necessary for the ISO 9001: 2015 standard, in case the organization seeks certification, it will undergo an audit, in which evidence will be sought with which it is sustained and show proper implementation of the QMS. The evidence is the documented information that has been collected in that period, which is six months. During the audits, if you find non-consistent information, it is understood as a nonconformity, which will be addressed in the short term.

\section{Results}

When making a diagnosis in Engineering and Business Process Consultants, it can be determined that 5 main processes are required, which are necessary for proper operation in the company's Quality Management System. The company has managed to develop internally protecting the confidentiality of the documentary process in each of its processes according to its interaction identified in Figure 6.

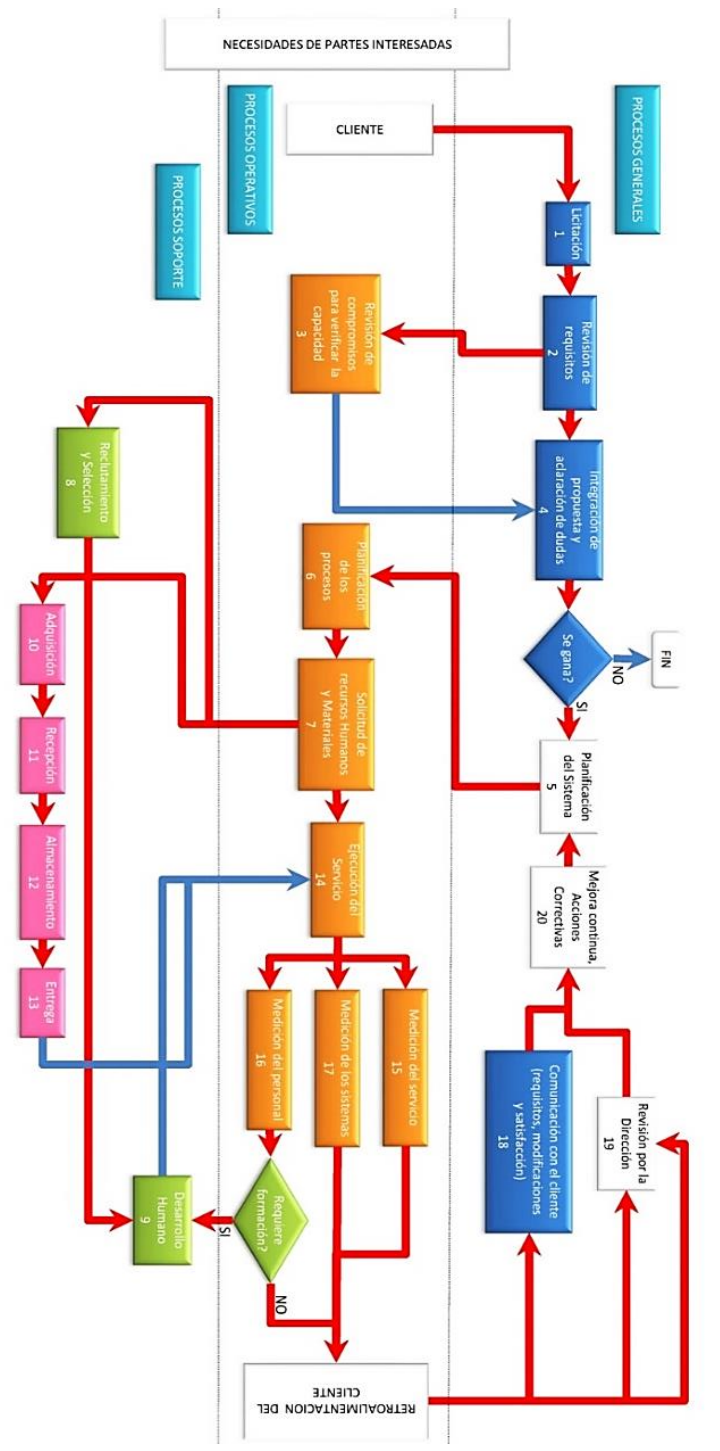

Figure 6 Organization process flow chart

RAMÍREZ-ROMÁN, Adolfo, SUÁREZ-ÁLVAREZ, Ángel, CHABATURANGA, Jacqueline and RODRÍGUEZ-RODRÍGUEZ, Luis Alberto. Designing a quality management system at ebpc engineering and business process consultants, S.C. ECORFAN Journal-Republic of Peru. 2019 
The link between the two institutions is strengthened through the social service and professional practices program. The graduate profile is strengthened through the experience and good practices that feed back the curriculum and its respective curriculum of the Industrial Engineering study program. The impact is consolidated in the obtaining of experiences in the process of application of criteria of international standard, and the development of the line of generation of knowledge "Management and Innovation of the Operations" of the Academic Body of the PE of Industrial Engineering "Innovation in Systems of Management "UV-CA-470 which consists in the Analysis and improvement of management models and systems that allow innovation and application of quality tools, logistics manufacturing, work study and administration in the Goods and services organizations.

For the organization to make effective decisions and identify current and future customer needs, it is recommended:

- Implement the QMS in the organization by processes according to the needs of operation and presence of nonconformities.

- That the management review and approve the documented information created during the design of the QMS, for its operation, expediting the processes that are carried out in the organization.

- Sensitize staff about what SGC is and what is a model of quality indicators, so that they have a thought of continuous improvement and risk management.

- Improve staff performance, processes, and procedures, setting goals with reference to competencies, which are measurable for improvement.

- Have staff participate more actively in decision making.

- Determine standards in general, support and operational processes.

- Train staff in the use of documents operating in the organization.

\section{Annexes}

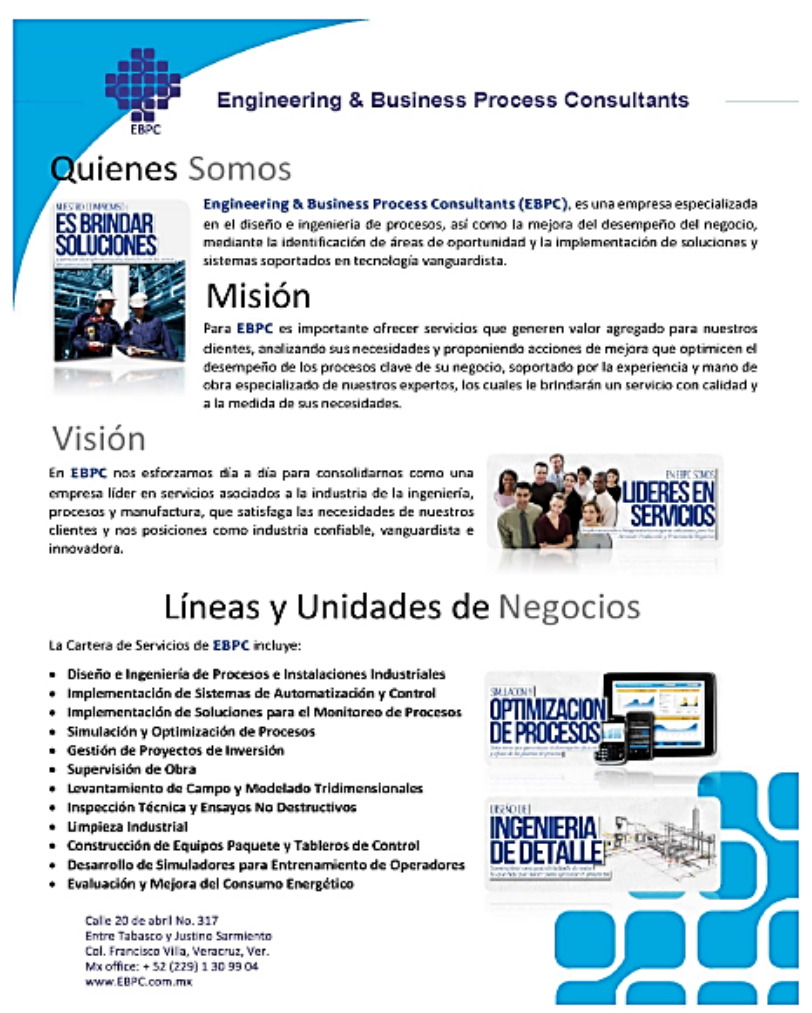

Figure 7 EBPC Curriculum Vitae, page 1

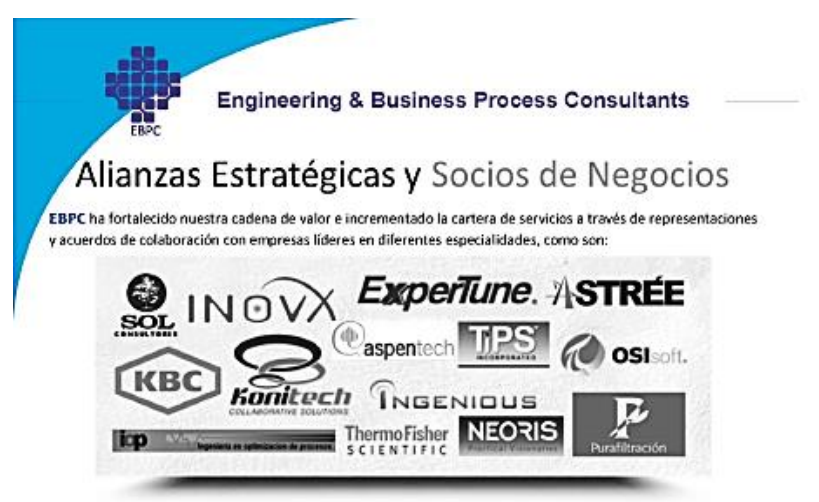

Algunos de Nuestros Proyectos

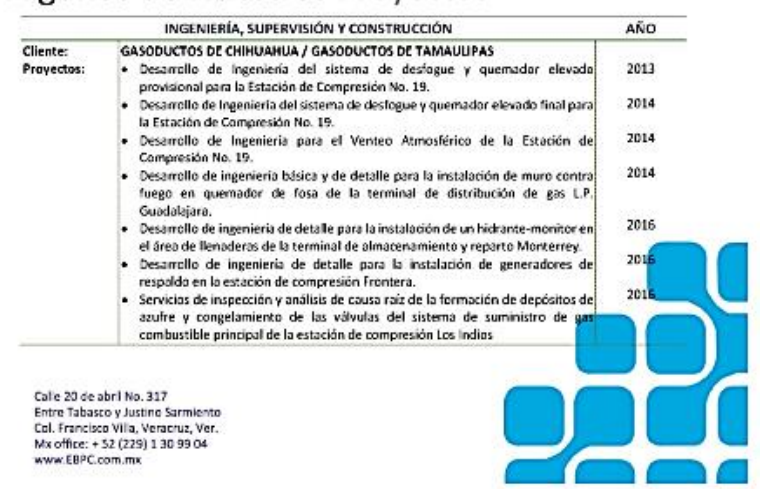

Figure 8 EBPC Curriculum Vitae, page 2 


\section{Acknowledgments}

Our sincere thanks to the management staff of the Company EBPC Engineering and Business Process Consultants, S.C. for its support in the participation in the advisory activities, and the decision making in applying the requirements of the ISO 9001 norm in its organizational structure, also, of the presentation of information of the organization through the reception work in the modality of Thesis of the Industrial Engineering student Ariana Vazquez Vazquez with registration $\mathrm{S} 14016771$ and her Co-advisor Mtro. Angel Suarez Alvarez.

\section{Conclusions}

According to the analysis of the requirements of the regulations, it was executed in the period from August to November 2018. During the diagnosis that was made in the organization, documented information was identified for the design of the QMS, the updating of formats, procedures, among other files. The documents that were in the organization's database were based on the ISO 9001: 2008 standard, so they were reviewed for evaluation and updating.

In the hypothesis raised in the investigation, five main processes in the organization were established, but it was determined that, for its proper functioning, four processes are necessary, however, the fifth process raised in the hypothesis is in the administration process. Due to the way in which it operates and the number of personnel in the organization. The two main processes are: ITV and IPC, which are in projects, both have the same inputs, but, according to the client's requirements, it is determined to which of the two processes the project to be carried out belongs. This was determined according to the analysis of the operation of the organization.

The organization seeks the design and implementation of the QMS to achieve an agile interpretation of the other standards for accreditation. A quality objective was established for the ITV and IPC processes with respect to the delivery time of the products or services that are available. The quality manual for the organization was prepared for the understanding of the operation.
Although the quality manual is not a requirement in the new version of the standard, its preparation for the design of the QMS and identifying areas of opportunity is essential for the general management of the organization. The documents that were developed and operated, have the EBINN code, because the SGC that was implemented, is based on 2 organizations which work together, these organizations are EBPC and INNTELLIA (https: //www.inntellia. com/).

The proposal was developed based on the documentation available to the organization, and considering the records of the design of the QMS, which started the organization, based on the 2008 version of ISO 9001. The documented information seeks to be flexible for the organization protected on the NAS Network by its acronym in English (network connected storage (NAS) store and share data for several computers, which can be accessed remotely).

\section{References}

Aguilardo, A. (2010). Propuesta para implementar un Sistema de Gestión de Calidad en la empresa "Filtración Industrial Especializada S.A. de C.V" de Xalapa, Veracruz (tesis de maestría). Universidad Veracruzana, Xalapa, Veracruz.

Álvarez García, J., Fraiz Brea, J. A., \& Del Río Rama, M. de la C. (2013). Implantación de un sistema de gestión de la calidad: beneficios percibidos. Utopia y Praxis Latinoamericana, 18(63), 379-407. Retrieved from http://search.ebscohost.com/login.aspx ?direct=t rue \&AuthType=ip,url,uid,cookie $\& \mathrm{db}=\mathrm{a} 9 \mathrm{~h} \& \mathrm{AN}$ $=108747711 \&$ lang=es\&site=ehost-live

Association, A. (2018). Los 14 Puntos sobre Calidad de Edwards Deming. [línea] Amamex.org.mx. Recuperado de: http://www.amamex.org.mx/articulos/Los-14-

Puntos-sobre-Calidad-de-EdwardsDeming.html [Consultado 30 de Sep. 2018].

Bayard, P. (1987). La calidad no cuesta. El arte de cerciorarse de la calidad. Distrito Federal, México, McGraw Hill Book Company. 
Carbonell Duménigo, C. A., Brunet Fernández, Á. J., \& Castro García, F. J. (2018). Procedimiento para evaluar la calidad de la gestión en la formación de los profesionales de las escuelas de fotografía del sector no estatal en Cuba. Infociencia, 22(1), 1-12. Retrieved from http://search.ebscohost.com/login.aspx?direct=t rue\&AuthType=ip,url,uid,cookie $\& \mathrm{db}=\mathrm{a} 9 \mathrm{~h} \& \mathrm{AN}$ $=132304187 \&$ lang=es\&site=ehost-live

Cañizal, A. (Ed.). (2006). Gestión de la Calidad: conceptos, enfoques, modelos y sistemas. España: Editorial Perarson Educación, S.A.

Child, J. (2015). Organization: Contemporary Principles and Practices, 2nd ed. Nidia, India. John Wiley \& Sons.

Dirección de una empresa: funciones y competencias clave. (s.f) Recuperado de: https://www.gestion.org/acerca-de-la-direccionen-una-empresa/ [Consultado 4 de Nov. 2018].

Evans, J., Lindsay, W. and Lindsay, W. (2008). Administración y control de la calidad. 7th ed. Mexico City: Cengage Learning Editores, S.A. De C.V.

Feigenbaum, A. y De la Campa Pérez Sevilla, M. (1994). Control total de la calidad. 3rd ed. México, D.F.: Compañia Editorial Continental.

Gillett, Jan. (2015) Implementing ISO 9001:2015: Thrill your customers and transform your cost base with the new gold standard for business management.

González, O., \& Arciniegas, J. (2016). Sistemas de Gestión de Calidad. Bogotá: Ecoe Ediciones. Gryna, F., Chua, R., \& De Feo, J. (2007). Método Juran. México: McGrawHill/Interamericana.

Gryna, F., Chua, R., \& De Feo, J. (2007). Método Juran. México: McGrawHill/Interamericana.

Guajardo Garza, E., \& Alanís Sánchez, F. (2000). Administración de la calidad total. México: Pax México.

Heras, I., Arana, G., César, C., Martín, C. and Añola, M. (2008). Gestión de la calidad y competitividad de las empresas CAPV.
Herrera, M. (2008). Diseño de un Sistema de Control de Calidad para una microempresa (tesis de maestría). Universidad Veracruzana, Xalapa, Veracruz.

López Gutiérrez, N., Martínez Pedregal, A., \& Muñiz Guilarte, M. (2017). Los sistemas de gestión de la calidad en el contexto universitario. Un enfoque basado en procesos. Folletos Gerenciales, 21(4), 232-244. Retrieved from http://search.ebscohost.com/login.aspx?direct=t rue \&AuthType=ip,url,uid,cookie $\& \mathrm{db}=\mathrm{a} 9 \mathrm{~h} \& \mathrm{AN}$ $=130249771 \&$ lang=es\&site=ehost-live

Lorenzo, O. (2007). Kaoru Ishikawa, un maestro de la Calidad Total | CAPACITACION EN COSTOS Y GESTION. [línea] Recuperado de: https://capacitacionencostos.blogia.com/2007/0 32706-kaoru-ishikawa-un-maestro-de-lacalidad-total.php [Consultado 18 Oct. 2018].

Mauch, Peter D. (2014) Administración de la Calidad: Teoría y aplicaciones. Editorial Trillas. 1a. Edición.

Mateo, R. (2010). Sistemas de Gestión de la Calidad. [Línea] Recuperado de: https://www.gestiopolis.com/sistemas-gestioncalidad/ [Consultado 4 Nov. 2018]

Neme, L. (2009). Diseño de un Sistema de Control de Calidad para revista LÍDER en Política y Negocios (tesis de maestría). Universidad Veracruzana, Xalapa, Veracruz.

Norma NMX-CC-9001-IMNC-2015 Sistemas de gestión de la calidad - Requisitos.

Norma NMX-CC-9000-IMNC-2015 Sistemas de gestión de la calidad - Fundamentos y vocabulario.

Norma NMX-CC-9001-IMNC-2015 Sistemas de gestión de la calidad - Requisitos.

Norma NMX-EC-17025-IMNC-2017, Requisitos generales para la competencia de los laboratorios de ensayo y calibración.

Norma

NMX-EC-17020-IMNC-2014, Evaluación de la Conformidad - Requisitos para el funcionamiento de diferentes tipos de unidades que realizan la verificación. 
Ramírez R., Adolfo. (2007). Modelo de indicadores de la calidad para evaluar los procesos de Metalyzinc, S.A de C.V. Universidad Veracruzana, Veracruz, Veracruz.

Rodríguez, M. (s.f.) Historia ISO 9001. [Línea] Recuperado de: http://www.normas9000.com/Company_Blog/h istoria-iso-9001.aspx [Consultado el 05 de Nov. 2018]

Rosario-Berenguer Ungaro, M., RafaelaHernández Rodríguez, N., Esther-Conde García, R., Gilart, R.-A., \& Yero, D.-D. (2018). Gestión de la calidad de la energía eléctrica. Revista de Ingenieria Energetica, 39(1), 62-68. Retrieved from

http://search.ebscohost.com/login.aspx?direct=t rue\&AuthType $=i p$, url,uid, cookie $\& d b=a 9 h \& A N$ $=128172415 \&$ lang $=$ es $\&$ site $=$ ehost-live

Rossetti, G., De Greef, M., \& Arcusin, L. (2016). Implementacion De La Gestion De La Calidad en Una Empresa Productora De Envases. Iberoamerican Journal of Industrial Engineering, 8(16), 147-166. Retrieved from http://search.ebscohost.com/login.aspx?direct=t rue $\&$ AuthType $=i p$,url,uid,cookie $\& d b=a 9 h \& A N$ $=122021387 \&$ lang $=$ es \& site $=$ ehost-live

Sánchez Cortés, J. (s.f.). Evolución Del Concepto Calidad. [Línea] Recuperado de: http://www.eumed.net/librosgratis/2008b/390/E volucion $\% 20 \mathrm{del} \% 20$ concepto $\% 20$ calidad.htm

[Consultado el 02 de Nov. 2018]

Torres Andrade, M. C., Alarcón, J., Berthet, A., Cantero, V., Llanquipichún, D., Sáez, D., \& Yáñez, I. (2016). Modelo de certificación de calidad para la gestión del cuidado en hospitales chilenos. Revista de Enfermagem Referência, 4(9), 65-74. https://doi.org/10.12707/RIV15015

Tovar, P. (s.f.). Genichi Taguchi: Biografía, Aportes y su Concepto de Calidad - Lifeder. Recuperado de: https://www.lifeder.com/genichi-taguchi/ [Recuperado de 21 Oct. 2018] 